Please do not remove this page

RMIT

UNIVERSITY

\title{
The capital asset pricing model (CAPM): the history of a failed revolutionary idea in finance? Comments and extensions
}

Moosa, Imad

https://researchrepository.rmit.edu.au/esploro/outputs/9921859197801341/filesAndLinks?institution=61RMIT_INST\&index=null

Moosa, I. (2013). The capital asset pricing model (CAPM): the history of a failed revolutionary idea in finance? Comments and extensions. Abacus, 49, 62-68. https://doi.org/10.1111/j.1467-6281.2012.00385.x Document Version: Accepted Manuscript

Published Version: https://doi.org/10.1111/j.1467-6281.2012.00385.x

Repository homepage: https://researchrepository.rmit.edu.au

(c) 2012 The Author, Abacus (c) 2012 Accounting Foundation, The University of Sydney.

Downloaded On 2023/04/26 10:06:04 +1000 
Thank you for downloading this document from the RMIT Research Repository.

The RMIT Research Repository is an open access database showcasing the research outputs of RMIT University researchers.

RMIT Research Repository, http://researchbank.rmit.edu.au/

\section{Citation:}

Moosa, I 2013, 'The capital asset pricing model (CAPM): the history of a failed revolutionary idea in finance? Comments and extensions', Abacus, vol. 49, pp. 62-68.

See this record in the RMIT Research Repository at:

https://researchbank.rmit.edu.au/view/rmit:24160

Version: Accepted Manuscript

Copyright Statement: (c) 2012 The Author, Abacus ( 2012 Accounting Foundation, The University of Sydney

Link to Published Version:

http://dx.doi.org/10.1111/j.1467-6281.2012.00385.x 
The Capital Asset Pricing Model (CAPM): The History of a Failed Revolutionary Idea in Finance? Comments and Extensions

\author{
Imad A. Moosa* \\ School of Economics, Finance and Marketing, RMIT \\ 239 Bourke Street \\ Melbourne, Victoria 3000 \\ Australia \\ E-mial: imad.moosa@rmit.edu.au
}

* I am grateful to the editor of this journal for inviting me to write this note. I would like to thank Michael Dempsey and John Vaz for useful comments on an earlier draft. 


\section{Introduction}

The capital asset pricing model (CAPM) and its extensions symbolise everything that is wrong with academic finance: models of financial markets and asset prices, the econometric testing of these models, and the perceived practical significance of the models. Despite the global financial crisis, and the devastation it has inflicted on countries and individuals, it is still "business as usual" for the true believers-those who think that markets cannot fail and that finance is like physics, a science that can produce reliable predictive models. Hundreds of papers have been written on the CAPM and its variants/extensions, but little concern has been expressed about the tendency of finance academics to squander a big portion of their intellectual capital on this endeavour.

This is why Dempsey's paper in this issue of this journal (Dempsey, 2012) is timely. He makes a number of interesting points that challenge the orthodoxy of the Chicago economics, including the CAPM foundation that markets are fundamentally rational and the proposition that the CAPM is a "revolutionary idea" that is associated with the other "revolutionary idea" of the efficient market hypothesis. He correctly argues that the CAPM has failed as a paradigm for asset pricing and discredits the idea that finance is a subject that is worthy of or suitable for "scientific enquiry". Another interesting point raised by Dempsey is that the continued defence of the CAPM by the true believers has led to the addition of other explanatory variables to the underlying model, without any explicit theory or even intuition, in an attempt to salvage the model typically through data mining. Dempsey reaches important conclusions. For example, he concludes that "the paradigm of the CAPM and efficient markets may need to be replaced with a paradigm of markets as vulnerable to capricious 
behaviour". He also concludes that "in a non-CAPM world, the practitioner needs to understand how markets function in disequilibrium, as well as in equilibrium, with the caveat that history never repeats itself”. The objective of this note is to evaluate and elaborate on the points raised by Dempsey.

\section{The Failure of CAPM}

Dempsey (2012) argues that the CAPM has failed as a paradigm for asset pricing — he is not alone in (correctly) thinking that way. The recognition of the failure of the CAPM comes after long years during which the model dominated financial economics to the extent that it has become to be known as "the paradigm" (Ross, 1978; Ryan, 1982). The model has been and is still used for estimating the cost of capital, evaluating the performance of managed portfolios, and for investment purposes.

The CAPM has failed the test of reality. Fama and French (2004) argue that "the empirical record of the CAPM is poor enough to invalidate the way it is used in applications”. The poor empirical performance of the CAPM may be a reflection of theoretical loopholes, simplifying assumptions and perhaps the difficulty of implementing a valid test (for example, the difficulty of constructing a market portfolio). The model is based on some assumptions that are truly ludicrous: no commissions, no bid-ask spreads, no taxes, investors view stocks only in a meanvariance space along the lines suggested by Markowitz (1952), and that investors can take any position without affecting the market price. These points have been discussed repeatedly in the literature, so I will not re-iterate. 
The CAPM stipulates that the expected return on an asset is linearly related to its beta only, thus excluding other potential explanatory variables. For me it stretches the imagination to suggest that a simple equation can explain the return on a stock on the basis of its beta, a measure of systematic risk. Beta itself is a useful concept, telling us how the stock is related to the overall market—hence it gives a reasonable portfolio management tip: if you expect the market to go up you should increase the number of high-beta stocks, and vice versa. To contend that beta alone can tell us what the expected return should be is far off the mark. A serious flaw of this conjecture is the proposition that market participants think exactly in the same way, paying attention to nothing but beta. The Economist (2011) correctly argues that "the problem is not just that investors do not know how the fundamentals... will develop" but also that "they do not know which other investors will choose to focus on”.

Fama and French $(1993,1996)$ found that betas alone cannot explain cross-sectional differences in stock returns - this is the same Fama who used to be enthusiastic about the CAPM (Fama and MacBeth, 1973). On the basis of their results, Fama and French pronounced the death of the CAPM, but there seems to be some sort of ambivalence about whether the Fama-French model is a replacement for or an extension of the CAPM. Dempsey's comments on how the CAPM relates to the Fama-French model exhibit this ambivalence. On the one hand, he is bewildered by the Fama-French denouncement of beta in combination with their inclusion of beta as an explanatory variable in their model. On the other hand, he argues that "the Fama and French threefactor model has made beta redundant as an explanatory variable, which makes sense given their studies confirming that beta has little or no explanatory power”. 
Lai (2011) comes to the strong but justifiable conclusion that the CAPM is a “tautology rather than an asset pricing model”. He uses mathematical reasoning to conclude that "the CAPM is useless and doomed for predicting the rate of return in the real world”. Efforts to salvage the CAPM have not changed the fact that the model is theoretically bankrupt, empirically unsupported, and practically useless at best and misleading at worst.

\section{The Failure of EMH and REH}

Dempsey (2012) criticises the CAPM foundation that markets are fundamentally rational, thus casting doubt on the related "revolutionary" ideas of the efficient market hypothesis (EMH) and the rational expectations hypothesis (REH). These hypotheses constitute gross misrepresentation of the facts on the ground.

As Dempsey (2012) argues, the efficient market hypothesis is claimed to be the most extensively tested hypothesis (for example, Smith 1990). Jensen (1978) went as far as claiming that "there is no other proposition in economics which has more solid empirical evidence supporting it than the efficient market hypothesis”. The EMH, developed by Fama (1970), stipulates that financial prices reflect all the available information relevant to the values of the underlying assets, which means that the price of an asset converges on its value fairly quickly. Interestingly, although Fama has undergone a change of heart with respect to the $\mathrm{EMH}$, he never acknowledged the failure of the hypothesis while enthusiastically declaring the death of the CAPM. 
To its benefit, and the detriment of the rest of the economy, the finance industry interpreted the EMH, with the help and encouragement of academia, to imply that the market is capable of pricing financial assets correctly and that deviations from fundamental values could not persist. The development of "financial engineering” was propelled by the EMH, in the sense that any complex security can be priced correctly through the market mechanism of arbitrage. As a result, financial sector gurus convinced politicians, regulators and investors that what they were doing was in the interest of the economy as they found alternative investment outlets and means of risk management-actually they produced various means for boosting risk as opposed to managing it.

The global financial crisis has dealt a severe blow, not only to the EMH but to the whole discipline of financial economics-neoclassical financial economics, to be precise. According to Harper and Thomas (2009), who were referring to what happened during the global financial crisis, "the disappearance of buyers.... from major financial markets, especially over-the-counter markets for derivatives, reinforces disaffection with Efficient Market Theory”. Quiggin (2009) points out that "the failure of the efficient markets hypothesis will have ramifications throughout economics and finance, and will require a thorough rethinking of the analysis of financial regulation”. Fox (2009) declares the triumph of the efficient market's critics "by showing why traditional market forces can sometimes be just as pervasive as the rational ones". Unfortuantely, The Economist (2011) is correct in arguing that "the efficient market hypothesis, like a Hollywood monster, has proven very hard to kill off”. 
The REH was developed by Thomas Sargent and Robert Lucas from the original sound idea of Muth (1961) (see, for example, Sargent, 1987). The problem with the $\mathrm{REH}$ is that it is plainly counter-factual, as it precludes heterogeneity in favour of some "representative agent", which is inherent in asset pricing models. The literature disputes the validity of the representative agent hypothesis, rejecting it in favour of heterogeneity, on the grounds that the former is inconsistent with observed trading behaviour and the existence of speculative markets. Indeed, it is arguable that there is no incentive to trade if all market participants are identical with respect to information, endowments and trading strategies.

\section{Finance as a Science}

Dempsey (2012) argues that "by the late 1950s, the prestige of the natural sciences had encouraged the belief that the modelling of decision-making and resource allocation problems could be identified through the elaboration of optimisation models and the general extension of techniques from applied mathematics”. Economics and finance are allegedly similar to physics, where behaviour is governed by laws and financial markets are like physical systems-by pushing a button the market moves in one direction rather than the other. This belief has led to the excessive and unnecessary mathematisation of economics and finance and the production of fancy but unrealistic models (including the CAPM).

The contribution of mathematics to finance has been hailed as a positive development. For example, Stuparu and Daniasa (2009) argue that "increasing activity in financial markets (particularly in derivatives trading) is goverened by mathematical models”, as if the mushrooming of trading in toxic assets has been a positive development. In 
reality, however, excessive mathematisation of economics and finance has resulted in work that has no relevance to reality. Vellupillai (2005) demonstrates that "mathematical economics is unreasonably ineffective... because the mathematical assumptions are economically unwarranted; ineffective because the mathematical formalisations imply non-constructive and uncomputable structures”. Likewise, Pani (2003) argues that "if we look beyond individual models to the actual practice of mathematical economics the role that subjective judgments play becomes quite evident”.

Referring to economics, or rather neoclassical economics, Horn (2009) argues that "we are witnessing the dismantling of an approach that, at least in its shallow mainstream version, has to make a series of absurd assumptions in order to reach any conclusion — with both the assumptions and the conclusions being astonishingly out of touch with reality. This is what the CAPM, EMH and REH are all about: incredible assumptions.

\section{Econometric Loopholes: Dodgy Techniques and Data Mining}

Econometrics was originally developed to serve as a means to an end: the means whereby economic and financial relations are estimated and tested. It has, however, become an end itself as we have witnessed a proliferation of econometric methods that add no value to the process of investigation. This is why van Meerhaeghe (1986) argues that "many econometrists [sic] are no longer interested in measurement, but in art for art's sake”. He correctly concludes that econometrics has become abstract mathematisation. 
Number crunching has overwhelmed our understating of financial markets with the development of the gimmicks of financial econometrics. Some elaborate models have been developed, including ARMA, ARIMA, ARFIMA, TAR and SETAR models. We also have neural networks, wavelet analysis and multi-chain Markov switching models. The Nobel Prize was awarded to Robert Engle for inventing ARCH models, which are designed to explain and predict financial volatility, but things did not stop there. There have been more sequels to ARCH than to Jaws, Rocky, Rambo and Die Hard put together. These sequels include GARCH, EGARCH, XARCH and $\mathrm{XYARCH}$ where $\mathrm{X}$ and $\mathrm{Y}$ can be replaced by any letter of the alphabet. Moosa (2011a, 2011b) demonstrates the failure of financial econometrics by showing that model sophistication does not make any difference for hedging effectiveness and that cointegration analysis does not tell us anything over and above what we learn from simple correlation analysis.

The biggest problem with the econometrics of asset pricing models is that crosssectional analysis is conducive to data mining, a problem that Dempsey (2012) refers to explicitly. Subrahmanyam (2010) argues that “our learning about the cross-section is hampered when so many predictive variables accumulate without any understanding of the correlation structure between the variables" and that "the tendency of scholars to use one methodology or the other raises the question of whether the results are robust to different methodology”. He is very sceptical about the robustness of the results derived from empirical asset pricing models. Black (1993) considers the three-factor model to be a result of data mining because trial with a large number of potential explanatory variables is bound to produce something that looks “nice”. 
In his paper Dempsey (2012) emphasises the problem of data mining by pointing out that "the trend of adding factors to better explain observed price behaviors has continued to dominate asset pricing theory”. Dempsey argues that "the simplest way to fit CAPM to the data is to replace the risk-free rate (typically the rate of return on short-term U.S. Treasury bonds) with some larger value, $R_{z}$, since that would adjust the intercept and explain the lower slope of the cross-sectional regressions”. Referring to the work of Black et al. (1972), he argues that "BJS use the data to calculate the required substitute rate, $R_{z}$, that offers the best fit. Mehrling (2007) describes $R_{z}$ as a "statistical fix in search of a theoretical explanation”.

In general, Dempsey (2012) wonders “why academic finance should be given to such a colossal commitment to data mining”. He makes a brilliant point by correctly arguing that "a good deal of finance is now an econometric exercise in mining data either for confirmation of a particular factor model or for the confirmation of deviations from a model's prediction as anomalies”. The love affair with data mining emanates from the desire to support one's prior convictions.

\section{Concluding Remarks}

This note is about the ideas raised by Dempsey (2012) in relation to the CAPM and its extensions. Several conclusions are reached that are in agreement with the propositions put forward by Dempsey. The CAPM is an inadequate model but the extensions are still lacking. These models result from the extensive use of data mining and defunct theorising. It is also concluded that two pillars of the CAPM, EMH and REH, have failed. 
It seems that academic finance will be in a better shape if we stop depending excessively on mathematical and econometric modelling and learn more from financial history and other social sciences. Finance, after all, is not physics and the CAPM is by no means Boyle’s Law. 


\section{References}

Black, F. (1993) Beta and Return, Journal of Portfolio Management, 20, 8-18.

Black, F., Jensen, M. and Scholes, M. (1972) The Capital Asset Pricing Model: Some Empirical Tests, in Jensen, M. (ed) Studies in the Theory of Capital Markets. New York: Praeger.

Dempsey, M. (2012) The Capital Asset Pricing Model (CAPM): The History of a Failed Revolutionary Idea in Finance? Abacus (this issue).

Fama, E. F. (1970) Efficient Capital Markets: A Review of Theory and Empirical Work, Journal of Finance, 25, 383-417.

Fama E., MacBeth J. (1973) Risk, Return, and Equilibrium: Empirical Tests, Journal of Political Economy, 81, 607-636.

Fama, E. and French, K. (1993) Common Risk Factors in the Returns on Stocks and Bonds, Journal of Financial Economics, 33: 3-56.

Fama, E. and French, K. (1996) Multifactor Explanations of Asset Pricing Anomalies, Journal of Finance, 51, 55-84.

Fama, E.F. and French, K.R. (2004) The Capital Asset Pricing Model: Theory and Evidence, Journal of Economic Perspectives, 18, 25-46.

Fox, J. (2009) The Myth of Rational Market, New York: Harper Collins.

Harper, I. and Thomas, M. (2009) Making Sense of the GFC: Where Did it Come From and What Do we Do Now, Economic Papers, 28, 196-205.

Horn, K. (2009) The Serendipity of Genius, Standpoint, 7 October. www.standpointmag.co.uk/node/2164/full.

Jensen, M. (1978) Some Anomalous Evidence Regarding Market Efficiency, Journal of Financial Economics, 6, 95-101. 
Lai, T-Y. (2011) Yes, the CAPM is Dead, Paper presented at the $19^{\text {th }}$ annual conference on Pacific Basin finance, economics, accounting and management, Taipei, 8-9 July.

Markowitz, H.M. (1952) Portfolio Selection, Journal of Finance, 7, 77-91.

Mehrling, P. (2007) Fisher Black and the Revolutionary Idea of Finance, New Jersey: John Wiley and Sons.

Moosa, I.A. (2011a) The Failure of Financial Econometrics: Estimation of the Hedge Ratio as an Illustration, Journal of Financial Transformation, 31, 67-71.

Moosa, I.A. (2011b) The Failure of Financial Econometrics: Assessing the Cointegration "Revolution”, Journal of Financial Transformation (forthcoming).

Muth, J.F. (1961) Rational Expectations and the Theory of Price Movements, Econometrica, 29, 315-335.

Pani, N. (2003) On Subjectivity in Mathematical Economics, Economic and Political Weekly, 38, 3686-3693.

Quiggin, J. (2009) Six Refuted Doctrines, Economic Papers, 28, 239-248.

Ross, S.A. (1978) The Current Status of the Capital Asset Pricing Model, Journal of Finance, 33, 885-901.

Ryan, R. J. (1982) Capital Market Theory-A Case Study in Methodological Conflict, Journal of Business Finance and Accounting, 9, 443-458.

Sargent, T.J. (1987) Rational Expectations, The New Palgrave: A Dictionary of Economics, London: Macmillan, 4, 76-79.

Smith, C.W. (1990) The Modern Theory of Corporate Finance (2nd edition), New York: McGraw-Hill. 
Stuparu, D. and Daniasa, C.I. (2009) Significance of Mathematics for Economics, Working Paper, University of Craiova. www.fse.tibiscus.ro/anale/Lucrari 2009/064.\%20Stuparu,\%20Danaiasa.pdf.

Subrahmanyam, A. (2010) The Cross-Section of Expected Stock Returns: What Have We Learnt from the Past Twenty-Five Years of Research?, European Financial Management, 16, 27-42.

The Economist (2011) Killing off the Monster, 26 February, 68.

van Meerhaeghe, M.A.G. (1986) Econometrics: An Appraisal, Journal of Economic Studies, 27, 316-325.

Velupillai, K.V. (2005) The Unrealistic Ineffectiveness of Mathematics in Economics, Cambridge Journal of Economics, 29, 849-872. 